\title{
各種形状寸法の $\mathrm{NaI}(\mathrm{Tl})$ シンチレーション検出器の $\gamma$ 線応答関数の整備と試験
}

\author{
森内 茂 ${ }^{* 1}$, 堤 正博 ${ }^{* 2}$, 斎藤 公明 *3
}

(2006 年 9 月 12 日受理)

(2007 年 2 月 1 日再受理)

\section{Construction of Response Functions for Various Cylindrical and Spherical NaI(Tl) Scintillation Detectors for Gamma Rays and the Test Results}

\author{
Shigeru MoRIUCHI ${ }^{* 1}$, Masahiro TsuTSUMI ${ }^{* 2}$ and Kimiaki SAITO*3
}

\begin{abstract}
Gamma ray spectra analyses using unfolding techniques and the dose evaluation are performed widely in the fields of environmental radiation monitoring and the relating environmental research. Various sizes and the shapes of NaI (Tl) scintillation detectors can be used depending on the dose levels. However, available response functions are generally limited to $3^{\prime \prime} \phi \times$ $3^{\prime \prime}$ cylindrical and $3^{\prime \prime} \phi$ spherical types and the energy range is roughly up to $3 \mathrm{MeV}$. In this paper, the response functions of eight types of cylindrical and spherical NaI (Tl) scintillation detectors (1" $\phi \times 1^{\prime \prime}, 2^{\prime \prime} \phi \times 2^{\prime \prime}, 3^{\prime \prime} \phi \times 3^{\prime \prime}, 4^{\prime \prime} \phi \times 4^{\prime \prime}, 5^{\prime \prime} \phi \times 4^{\prime \prime}$ cylindrical, and $2^{\prime \prime} \phi, 3^{\prime \prime} \phi, 5^{\prime \prime} \phi$ spherical) were determined. The energy ranges were extended to $10 \mathrm{MeV}$ in maximum. The some response functions reported in literatures were unfolded using our response matrices for comparison and the relative characteristics were discussed.
\end{abstract}

KEY WORDS: gamma ray, spectrum analysis, unfolding, environmental radiation monitoring, NaI(Tl) scintillation detector, various sizes and shapes, response function, response matrix, extended energy range .

\section{I 緒言}

$\mathrm{NaI}$ (T1) シンチレーション検出器, $\mathrm{Ge}$ 半導体検出器

*1 (財) 原子力安全技術センター防災技術部 ; 東京都文京区白山 5-1-3-101（ 112-8604）

Division of Emergency Preparedness Technology, Nuclear Safety Technology Center; 5-1-3-101, Hakusan, Bunkyo-ku, Tokyo 1128604, Japan.

E-mail: moriuchi@nustec.or.jp

*2 (独) 日本原子力研究開発機構東海研究開発センター原子力科 学研究所放射線管理部; 茨城県那珂郡東海村白方白根 2-4 ( ( 319-1195)

Department of Radiation Protection, Nuclear Science Research Center, Tokai Research Technology Center, Japan Atomic Energy Agency; 24, Tokai-mura, Ibaraki 319-1195, Japan. E-mail: tsutsumi.masahiro@jaea.go.jp

*3 (独) 日本原子力研究開発機構原子力基礎工学研究部門; 茨城 県那珂郡東海村白方白根 2-4（广 319-1195）

Nuclear Science and Engineering Directorate, Japan Atomic Energy Agency; 2-4, Tokai-mura, Ibaraki 319-1195, Japan.

E-mail: saito.kimiaki@jaea.go.jp
を使った $\gamma$ 線スペクトル解析は, 低レベルの環境放射線 に関する放射線物理研究, 線量率評価, 環境放射線モ二 タリング等の分野で広く実施されている。パルス波高ス ペクトル測定に使われる放射線検出器には， $\gamma$ 線の検出 効率が高く, 全吸収ピークの効率が高い $\mathrm{NaI}(\mathrm{Tl})$ シンチ レーション検出器, エネルギー分解能が高くピーク識別 能が優れた $\mathrm{Ge}$ 半導体検出器が従来からよく使用されて いる。これらを使用する標準的なマニュアルとして文部 科学省が取りまとめた「空間 $\gamma$ 線スペクトル測定法」 （放射能測定法シリーズ 20）1）があり，環境放射線モ二 タリング分野での活用を中心に測定解析法や代表的な $\mathrm{NaI}$ (T1) 検出器の応答関数がまとめられている。しかし 現実には一部を除き, 応答関数はエネルギー間隔が粗く, 且つ対象 $\gamma$ 線のエネルギー範囲も上限が $3 \mathrm{MeV}$ 程度ま でで，自然放射線を評価対象にした使用に特定されてい る。また, 応答関数が整備されている検出器の形状, 寸 法が限定されていて, 测定するフルエンス率レベルやエ 
ネルギー範囲に合わせて任意に選んで利用できないとい う課題があった。

特に近年，線量評価単位が吸収線量率やカーマ率，さ らにシーベルト単位へと多様化が進み，これに伴って線 量評価が単純に物理量の測定に止まらない分野へ展開し ている。測定されたパルス波高スペクトル情報から線量 を評価する方法の整備はこのような事態へある程度柔軟 に対応するという意味では利点がある。放射線エネル ギースペクトル，すなわち空間のフルエンスと多様な線 量の関係については，国際放射線単位測定委員会 $(\text { ICRU })^{2-4)}$ や国際放射線防護委員会 (ICRP $)^{5,6)}$ の報告 書において，放射線物理的な理論解析によるフルエンス と線量の諸単位を関連付ける換算係数，線量単位相互間 の換算関係を裏付ける資料を提供している。

これまでも線量概念や線量単位の変更を経験し，変更 があるたびに適宜，換算関係が見直され，従来の単位か ら新しい単位への対応が進められてきた。大抵の場合こ のような対応で問題はないと思われるが，スペクトルの ような基本測定デー夕から線量評価ができるような多様 性を確保しておくことも重要であり，基本量としてのフ ルエンス，すなわちエネルギースペクトルから線量を算 出する線量評価方法を確立しておけげ，諸概念の変更へ の対応もスムーズに進めることが可能と思われる。

以上のような経緯を踏まえ，現在一般に広く使用され ている各種サイズ，形状の $\mathrm{NaI}(\mathrm{Tl})$ 検出器について応答 関数を改めて整備するとともに，従来から活用されてき た応答関数との比較を試みた。

\section{II 応答関数の整備}

\section{（1）整備に用いた基本の応答関数}

ここで新たに整備を目指した応答関数は，対象 $\gamma$ 線工 ネルギーの上限を最大 $10 \mathrm{MeV}$ ，応答関数の $\gamma$ 線エネル ギーの刻みを $10 \mathrm{keV}$ 程度の高いエネルギー分解精度を 目標とした。応答関数の作成には，単一エネルギーの $\gamma$ 線を放出する精度の高い線源があれば，実験的に得るこ とも可能であるが，任意の $\gamma$ 線エネルギーの線源を得る ことは現実に困難である。このような事情から通常，計 算で得られた応答関数を基本にして，入手できる線源で 確認の上使用するのが一般的である。要求される線量評 価精度に見合う高い精度の応答関数を計算できるモンテ カルロ計算コードとして， $\mathrm{NaI}(\mathrm{Tl})$ シンチレーション検 出器応答関数専用の MARTHA ${ }^{7 \sim 9)}$, あるいは EGS4 ${ }^{10}$, 11)，MCNP12)のような汎用のモンテカルロ計算コードが 知られている。 $\gamma$ 線エネルギー $10 \mathrm{keV}$ 間隔で $10 \mathrm{MeV}$ までの範囲で応 答関数を計算するには，1,000 個の $\gamma$ 線エネルギーに対 応する応答関数を計算しなければならない上に，統計的 に高い精度を得るには十分なヒストリー数（大射光子数 10 万から 100 万程度）で計算する必要がある。これだ けの数のモンテカルロ計算を検出器ごとに実施するに は，相当量の計算時間と作業量を必要とする。また，応 答関数のチャンネル幅を変更した場合には追加の計算が 必要となる場合もある。このため通常, 代表エネルギー 数を絞り，パルス波高スペクトルを内挿する方法がとら れる。ここでは基本的にこの方法に属する方法で応答関 数の整備を進めた。

内挿に用いた基本応答関数は斎藤らが開発したモンテ カルロ計算プログラム MARTHA ${ }^{7}$ 9) で計算したもの で， $\gamma$ 線の追跡ヒストリー数をほほ 10 万の条件で計算 した $40 \mathrm{keV}$ から $10 \mathrm{MeV}$ までの $\gamma$ 線エネルギー 28 点の

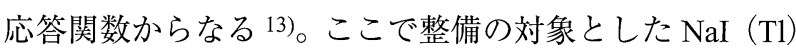
シンチレーション検出器は， $1^{\prime \prime} \phi \times 1 ", 2$ " $\phi \times 2$ " 3 " $\phi \times$ $3^{\prime \prime}, 4 " \phi \times 4^{\prime \prime}, 5^{\prime \prime} \phi \times 4^{\prime \prime}$ の 5 種類の円柱形， $2^{\prime \prime} \phi ， 3^{\prime \prime} \phi$, $5 " \phi$ の 3 種類の球形シンチレータで, 日本工業規格 (JIS) の検出器構造，材質からなるものである。 $\mathrm{NaI}(\mathrm{Tl})$ シン チレーション検出器の構造は可能な範囲で忠実にモデル 化した。検出器容器材料（アルミニウム），厚み，反射 材等をモデルに組み入れることによって容器材料等から の散乱 $\gamma$ 線，二次電子等の影響を忠実に再現するととも に, 二次電子の減速シミュレーションの過程で，吸収エ ネルギー密度に依存した発光効率の違いで生じるパルス 波高スペクトルの非直線性についても考慮した。文献 13 のモンテカルロ計算で想定された $\gamma$ 線エネルギー, チャネル幅，入射 $\gamma$ 線数を Table 1 に示す。

計算結果の精度については，参考文献 7,8 8 で，強度 が正確に分かっている点線源を用い，計算と同一の照射

Table 1 Gamma ray energies, channel width and history number of response functions.

\begin{tabular}{lcc}
\hline $\begin{array}{c}\text { Gamma ray Energy } \\
(\mathrm{MeV})\end{array}$ & $\begin{array}{c}\text { Channel Width } \\
(\mathrm{keV})\end{array}$ & $\begin{array}{c}\text { Number of Incident } \\
\text { Gamma ray }\end{array}$ \\
\hline $0.04,0.005,0.06$ & 1 & 100,000 \\
$0.08,0.10$ & & 100,000 \\
\hline $0.13,0.165,0.20$ & 2 & 100,000 \\
\hline $\begin{array}{l}0.30,0.40,0.50 \\
0.514,0.60,0.662\end{array}$ & 5 & 100,000 \\
\hline $0.80,0.835,1.00$ & 10 & 100,000 \\
\hline $\begin{array}{l}1.293,1.50,1.835 \\
2.00\end{array}$ & 20 & 100,000 \\
\hline $2.50,2.754,3.00$ & 50 & 100,000 \\
4.00 & & \\
\hline $6.00,8.00,10.0$ & 100 & \\
\hline
\end{tabular}


条件で測定したパルス波高スペクトルと計算した応答関 数を比較し, 全検出効率, ピーク計数効率, 全体のスペ クトル形状等が正確に計算できていることが確認されて いる。この比較においては, ${ }^{241} \mathrm{Am},{ }^{85} \mathrm{Sr},{ }^{137} \mathrm{Cs},{ }^{54} \mathrm{Mn},{ }^{88} \mathrm{Y}$ 線源の距離を結晶表面から $10 \mathrm{~cm}$ から $30 \mathrm{~cm}$ まで変化さ せ， $60 \mathrm{keV}$ から $1.83 \mathrm{MeV}$ のエネルギー範囲で比較を行 い, ピーク検出効率で数\%以内, 周囲からの散乱線の影 響を受ける全検出効率においても5\%以内でほとんどの 場合実験值と計算值が一致することを確認した。さらに， ${ }^{24} \mathrm{Na}$ 点線源からの $2.754 \mathrm{MeV} \gamma$ 線, ならびに原子炬周辺 で観察される ${ }^{14} \mathrm{~N}$ からの $6.13 \mathrm{MeV} \gamma$ 線に対しても, 応 答関数の相対的な形状が実測值と良く一致することが確 認されている7〜9,14)。

なお，ここで用いた基本応答関数には，

(1) NaI 結晶の中で吸収された吸収エネルギースペクト ル（二次電子のエネルギーに対応した発光効率を考 慮）を示すもの，

(2)光電子増倍管を経て統計的に分散した吸収エネルギ ースペクトル（共にパルス波高スペクトルに相当）

として示したもの， がある。ここでは $\gamma$ 線の検出器内における吸収反応別ス ペクトルの形状を正確に知る必要上, 統計的に分散のな いスペクトルを内挿の基本スペクトルとして用い，内挿 後必要に応じ統計分散を付与することとした。

(2) 応答関数の内挿と結果の評価

(i) 要素別スペクトル形状の扱いとエネルギーパラメ 一夕の内挿法

応答関数の内挿法として一般的に，1）パルス波高ス ペクトルの同一パルス波高毎の強度を全 $\gamma$ 線エネルギー 範囲に亘って内挿する方法，2）パルス波高スペクトル 分布の全吸収ピークの位置を 1 としてエネルギーを基準
化し，1）と同様な方法で内挿する方法，等が一般的で あるが，高い精度で内挿するためには何れの場合もスぺ クトル形状が連続して変化する程度，すなわち不連続に 跳躍しない程度の $\gamma$ 線エネルギー間隔で基本応答関数が 得られていることが必要である。ここで用いた基本応答 関数は $40 \mathrm{keV}$ から $10 \mathrm{MeV}$ の範囲で 28 個，1 チャンネ ルあたりのエネルギー幅は $\gamma$ 線エネルギーで異なってい る。ここで整備を目指した応答関数は $\gamma$ 線エネルギー $10 \mathrm{keV}$ 幅の細かいエネルギー間隔のもので，Table 1 に 示すような基本応答関数からでは単純な内挿法では高い 精度のものは得られない。このため，ここで採用した応 答関数の内挿は次に示すような方法により行った。

この方法はパルス波高スペクトルを，これを構成する 各種反応別寄与分布別に分解し，それぞれの成分のスペ クトル形状を数式による近似モデルで表わし， $\gamma$ 線のエ ネルギーに依存して変化する各成分の形状，効率を $\gamma$ 線 やパルス波高エネルギーに関するパラメータで一般化す る方法で，成分別の各種スペクトルを加算・重曽するこ とによって全体のパルス波高スペクトルを合成する方法 である。この方法についてはすでに参考文献 15 に報告 しており，その有効性については実証されていることか ら同じ方法を踏襲しているが，分解スペクトル成分ごと の関数表現パラメータの改良，成分の細分化等を進め， 精度の改善を達成している。これら成分別の各種スペク トルを加算・重畳する方法の概要は以下の通りである。

（ii）反応別の構成スペクトルの発生法

ヒストリー数 10 万程度では，スペクトルを構成する 各種の反応の確率が小さいエネルギー領域では，1 ビン 当り（チャンネル相当） $10 \mathrm{keV}$ 幅に入るイベント数は小 さく，統計的に形状が定まりにくい。この問題を解決す る方法として前回の報告および本報告では，モンテカル

Table 2 Functions and relating parameters for generating respective spective spectral elements.

\begin{tabular}{|c|c|c|c|}
\hline \multirow{2}{*}{ Item } & \multirow{2}{*}{ SPECTRAL ELEMENTS } & FUNCTION AND RELATING PARAMETERS FOR GENERATING EACH SPECTRALELEMENT \\
\cline { 3 - 4 } & Total absorption peak & Function for Forming Spectral Shape & Relating Parameters \\
\hline 1 & K-X ray peak & $\delta$-function & Peak efficiency \\
\hline 2 & Compton spectrum & Coupling of rectangle and exponential function & Peak and K-X ray escape efficiencies \\
\hline 3 & Over-tailing of Compton edge & Exponential function & Efficiency of over Compton components \\
\hline 4 & $\begin{array}{c}\text { Equivalent to the response function of } \\
\text { primary photon of } 0.511 \mathrm{MeV}\end{array}$ & $\begin{array}{c}\text { Peak Efficiency of } 0.511 \mathrm{MeV} \\
\text { pulse height spectrum }\end{array}$ \\
\hline 5 & $\begin{array}{c}\text { Spectrum of 0.511 MeV Annihilation } \\
\text { photon from canning }\end{array}$ & $\begin{array}{c}\text { Annihilation related spectrum } \\
\text { by Monte Carlo calculation }\end{array}$ & $\begin{array}{c}\text { Compton efficiencies of single } \\
\text { and double escape spectrum }\end{array}$ \\
\hline 6 & $\begin{array}{c}\text { Spectrum due to positron } \\
\text { annihilation in NaI(Tl) }\end{array}$ & $\delta$-function & $\begin{array}{c}\text { Efficiencies of single escape } \\
\text { and double escape peak }\end{array}$ \\
\hline 7 & Single and double escape peak & Exponential function & Efficiency of tailing component \\
\hline 8 & Tailing after double escape peak & $\begin{array}{c}\text { Efficiencies of broard component } \\
\text { and back scattering component }\end{array}$ \\
\hline 9 & $\begin{array}{c}\text { Broad spectrum components } \\
\text { from canning }\end{array}$ & $\begin{array}{c}\text { Coupling of rectangle function } \\
\text { and exponential function }\end{array}$ \\
\hline
\end{tabular}


ロ計算による応答関数の解析から反応別の形状を近似す る表現式を予め決めておき，内挿の段階でビン毎の統計 誤差の影響が出ないような方法を採用している。全吸収 ピーク，K-X 線エスケープスペクトル，コンプトンスペ クトル等の各スペクトル成分のほか, NaI 容器からの散 乱線等（コンプトン散乱，二次電子入射，消滅 $\gamma$ 線寄与 分等）の反応別のスペクトル成分はシミュレーション計 算による各エネルギーの応答関数を分解する方法で求め た。要素別の反応スペクトル分布は近似する関数, 数式 でフィッティングした。

成分別のスペクトル形状は基本的に指数関数と台形関 数の組み合わせで表現し，各スペクトル成分の発生効率 やスペクトル形状表現パラメータは各基本応答関数の值 をエネルギー内挿する方法で決定した。今回の報告で取 り扱った主要なエネルギー内挿パラメータの種類, 形状 表現関数形は Table 2 に揭げる通りである。前回の報告 と比べ, パラメータの数, 形状表現関数の数が多く， ス ペクトル形状の近似精度が向上している。Fig. 1 に，3" $\phi \times$ 3 " $\mathrm{NaI}(\mathrm{Tl})$ シンチレータの成分別近似スペクトルの例を, また，同じく $3^{\prime \prime} \phi \times 3^{\prime \prime} \mathrm{NaI}(\mathrm{T} 1)$ の各種エネルギーガンマ 線の合成パルス波高スペタトルの例を Fig. 2 に，基本応
答関数であるモンテカルロ計算スペクトルと比較して掲 げる。基本のモンテカルロ計算スペクトルとよく一致し ていることが分かる。

(iii) 応答関数の合成結果

元のモンテカルロ計算で想定された $\gamma$ 線エネルギー以 外の部分の応答関数パラメータの内捚によって連続性が 確保されていることを示す例を，同じく $3^{\prime \prime} \phi \times 3^{\prime \prime} \mathrm{NaI}$ （T1）の場合について Fig. 3 に示す。合成応答関数は統 計的な分散の無いもの（2.1の(1)）と統計的分散処理を 行ったもの（2.1の(2)）が得られているが, Fig. 3 には 後者を示す。また, Fig. 4 は, 合成した統計的に分散の 無い応答関数行列を使って，モンテカルロ計算による応 答関数（基本応答関数）をアンフォールディングして得 た $\gamma$ 線フルエンスである。ストリッピング法を用いてア ンフォールディングを行っているために，アンフォール ディング後のスペクトルのピークが広がりを持っている が，ピーク位置以外の擬似スペクトルは殆ど現れていな い。これは応答関数の特徵的な形状が精度良く再現され， アンフォールディングが適切に行われたことを示してい る。分散したスペクトルを積分した值は基本応答関数計 算時の照射条件であるフルエンス（100,000 photons/
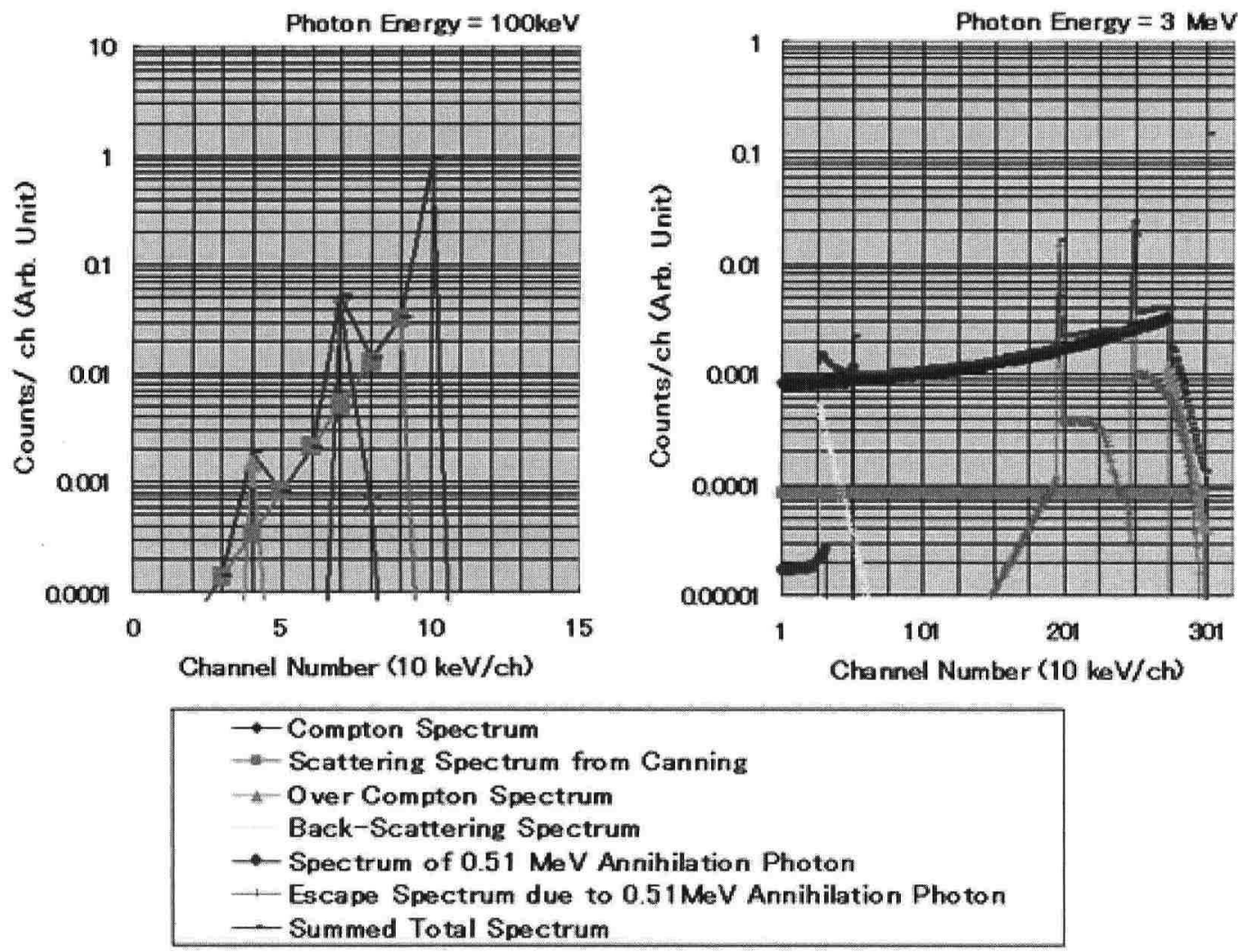

Fig. 1 Typical elemental spectra composing the response functions and full spectra at the photon energies of $100 \mathrm{keV}$ and $3.0 \mathrm{MeV}$. 

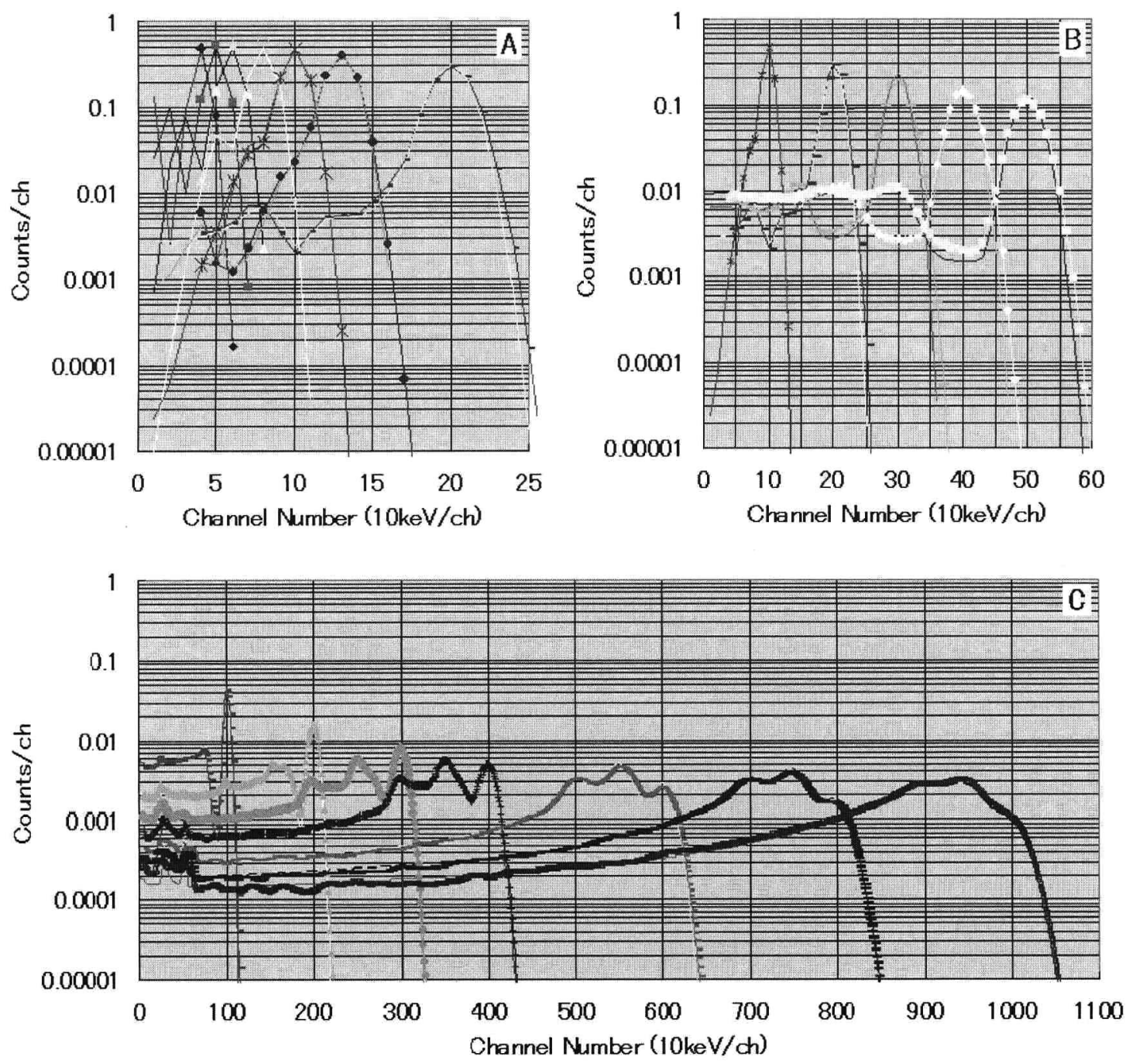

Fig. 2 Comparisons of original and reconstructed response functions of the selected photon energies; A: $40 \mathrm{keV}-200 \mathrm{keV}$, B: $100 \mathrm{keV}-500 \mathrm{keV}, \mathrm{C}: 1.0 \mathrm{MeV}-10 \mathrm{MeV}$. Original response functions are shown with makers, and reconstructed ones are with lines.
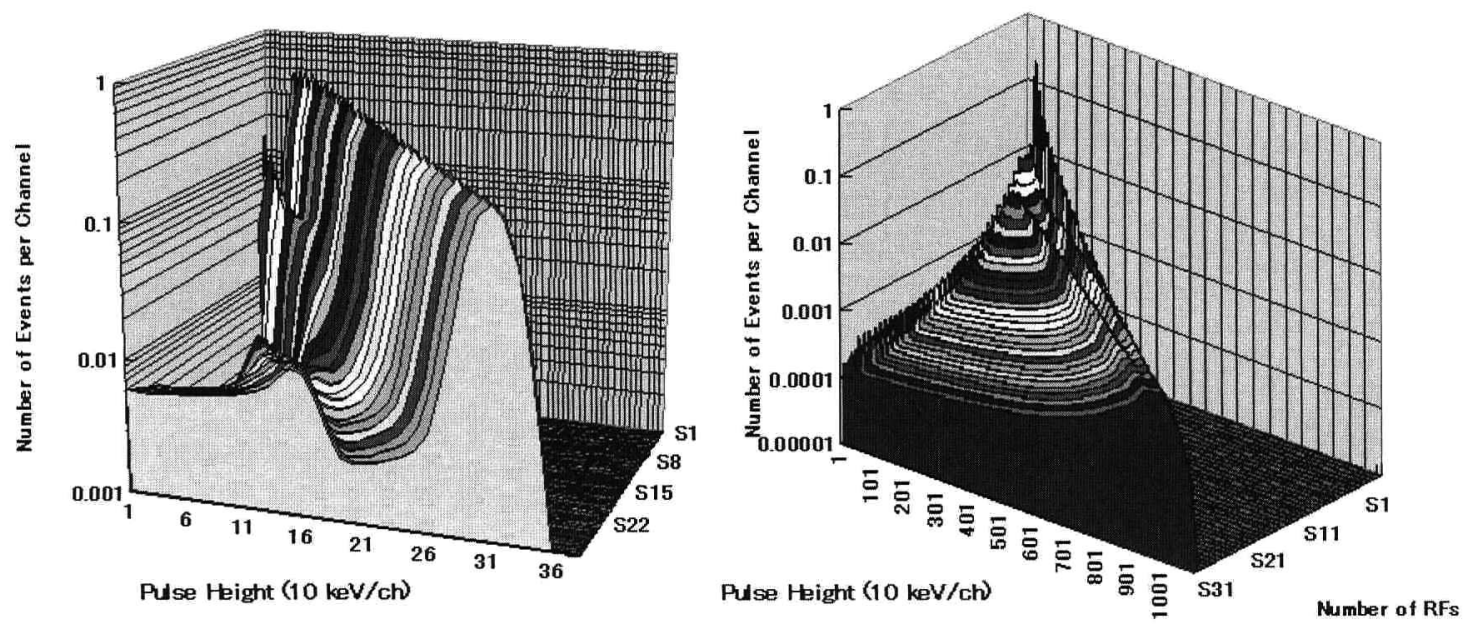

Fig. 3 Schematic array of response functions of $3^{\prime \prime} \phi \times 3^{\prime \prime} \mathrm{NaI}(\mathrm{Tl})$ scintillation detector.

A: displayed up to $300 \mathrm{keV}$ in $10 \mathrm{keV}$ intervals,

$\mathrm{B}$ : displayed up to $10 \mathrm{MeV}$ in $300 \mathrm{keV}$ intervals. 
$45.6 \mathrm{~cm}^{2}=2,193$ photon $\cdot \mathrm{cm}^{-2}$ ) をよく再現している。（詳 細については以下に述べる解析結果を参照)

以上に述べた方法により応答関数は $40 \mathrm{keV}$ から $10 \mathrm{MeV}$ の範囲で連続的に合成することができたが， NaI (Tl）検出器の大きさ, 種類によってスペクトルの近似 精度に違いが見られ，実用的なエネルギー範囲に差が出 た。Fig. 5, Fig. 6 は, 各サイズの円柱形, 球形 $\mathrm{NaI}(\mathrm{Tl})$ シンチレータについて内挿・合成した応答関数行列で基 本応答関数をアンフォールディングし，線量換算した結 果を示したもので，アンフォールディングで得られたス ペクトル解析結果を全エネルギー範囲に亘って積分した フルエンスまたは線量換算值を, 場の標準のフルエンス または線量で除した比で示している。この結果を見ると サイズの大きいシンチレータでは合成応答関数の近似精 度が高く，また，サイズが小さくなるとともに高エネル ギー側でややマイナス側にシフトしていることが分か る。このことは合成した応答関数は元の応答関数よりも 過大に再現されていることを意味している。

応答関数の近似精度の影響を受け高エネルギー側では 入射 $\gamma$ 線エネルギー以外のエネルギー領域に擬似ピーク が見られる場合があり，積分值が見かけ上良好な結果を 示しても解析スペクトル分布が乱れている場合がある。 このような領域を除外し，全エネルギー範囲に亘って精 度の高い解析結果が得られるエネルギー範囲を示したの が Table 3 である。精度の高・低の判断については，ア ンフォールディングによって得られた $\gamma$ 線エネルギース

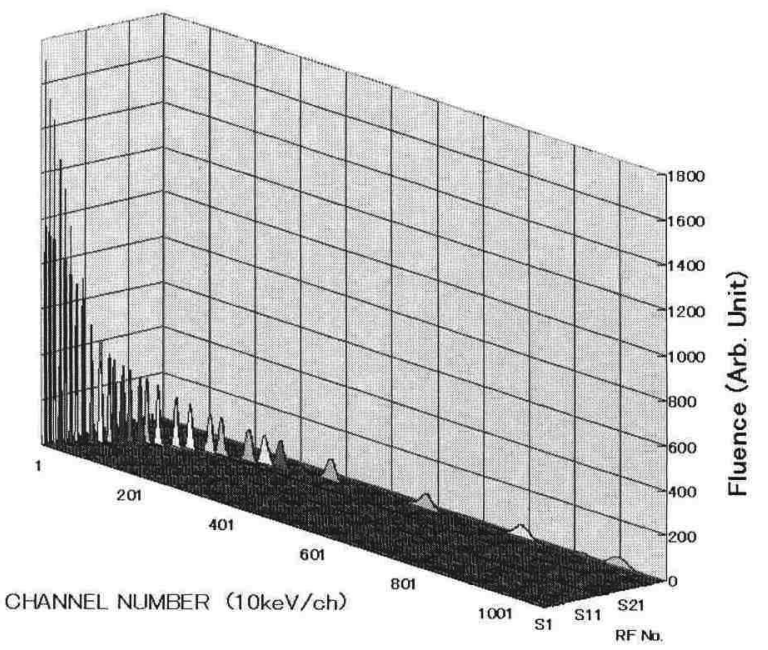

Fig. 4 Results of unfolded photon spectra of original response functions for $3^{\prime \prime} \phi \times 3^{\prime \prime} \mathrm{NaI}(\mathrm{Tl})$ by using the reproduced response matrix.
ペクトル分布に主 $y$ 線エネルギー以外に目立った擬似ス ペクトルが出現せず，理論値とのフルエンスと線量換算 值の比が $5 \%$ に入ることを選定の基準とした。良好な 解析結果が得られていれば，フルエンスと線量換算值は 1.0 に近い值となっている。

Fig. 5, Fig. 6 に示すような積分して得られるフルエン ス率や線量率の場合に比べ，エネルギー範围はやや狭い ことが分かる。なお， $40 \mathrm{keV}$ 点に現れている比率の低下 は $40 \mathrm{keV}$ スペクトル成分の一部が $30 \mathrm{keV}$ チャンネル側 に統計的に分散している（解析結果には反映されない） ことによるものである。この誤差は他のエネルギー域で の誤差とともに解析後修正は可能である。

\section{III 実測波高スペクトル，既存応答関数の解析試験と考察}

（1） ${ }^{226} \mathrm{Ra}$ 標準線源の実測波高スペクトルのアンフォー ルディング試験

正確な応答関数を実験により得るには強度が正確で極 力吸収を少なくした点線源あるいは容積が小さく従って 吸収・散乱の少ない線源を用いる必要がある。この種の 線源としてスペクトル検出器のピーク効率の测定やエネ ルギー校正に用意された各種の放射能標準線源が利用で き, 計算で求めた応答関数の精度の確認に利用できる。 得られるパルス波高スペクトルはそのまま応答関数相当 となる。また，線量率で值付けされた線源は，線源容器 自体による吸収や散乱線成分を伴う場合があり，純粋の 単色エネルギーの $\gamma$ 線として取り扱えない場合が多い が, 線量率で值付けされているため線量評価精度の確認 に使うことができる。各種線源， $\gamma$ 線エネルギーのパル ス波高スペクトルの解析例については他の報告 ${ }^{15)} に$ 委 ね，一例として ${ }^{226} \mathrm{Ra}$ 線量率基準 $\gamma$ 線源を用いて標準照 射した 3" $\phi$ 球形 $\mathrm{NaI}(\mathrm{Tl})$ 検出器のパルス波高スペクトル の解析試験の結果を以下に示す。

Table 3 Covering energy ranges of response functions different between various sizes and shapes of the $\mathrm{NaI}(\mathrm{Tl})$ scintillators

\begin{tabular}{cc}
\hline $\begin{array}{c}\text { Type, Shape \& Size of } \\
\text { NaI(Tl) Scintillator }\end{array}$ & $\begin{array}{c}\text { Energy Ranges without Spurious Energy } \\
\text { Peaks after Unfolding }\end{array}$ \\
\hline $1^{\prime \prime} \phi \times 1^{\prime \prime}$ cylindrical & $40 \mathrm{keV}-3.2 \mathrm{MeV}$ \\
$2^{\prime \prime} \phi \times 2^{\prime \prime}$ cylindrical & $40 \mathrm{keV}-4.4 \mathrm{MeV}$ \\
$3^{\prime \prime} \phi \times 3^{\prime \prime}$ cylindrical & $40 \mathrm{keV}-10 \mathrm{MeV}$ \\
$4^{\prime \prime} \phi \times 4^{\prime \prime}$ cylindrical & $40 \mathrm{keV}-10 \mathrm{MeV}$ \\
$5^{\prime \prime} \phi \times 4^{\prime \prime}$ cylindrical & $40 \mathrm{keV}-10 \mathrm{MeV}$ \\
\hline $2^{\prime \prime} \phi$ spherical & $40 \mathrm{keV}-5.0 \mathrm{MeV}$ \\
$3^{\prime \prime} \phi$ spherical & $40 \mathrm{keV}-6.0 \mathrm{MeV}$ \\
$5^{\prime \prime} \phi$ spherical & $40 \mathrm{keV}-10.0 \mathrm{MeV}$ \\
\hline
\end{tabular}



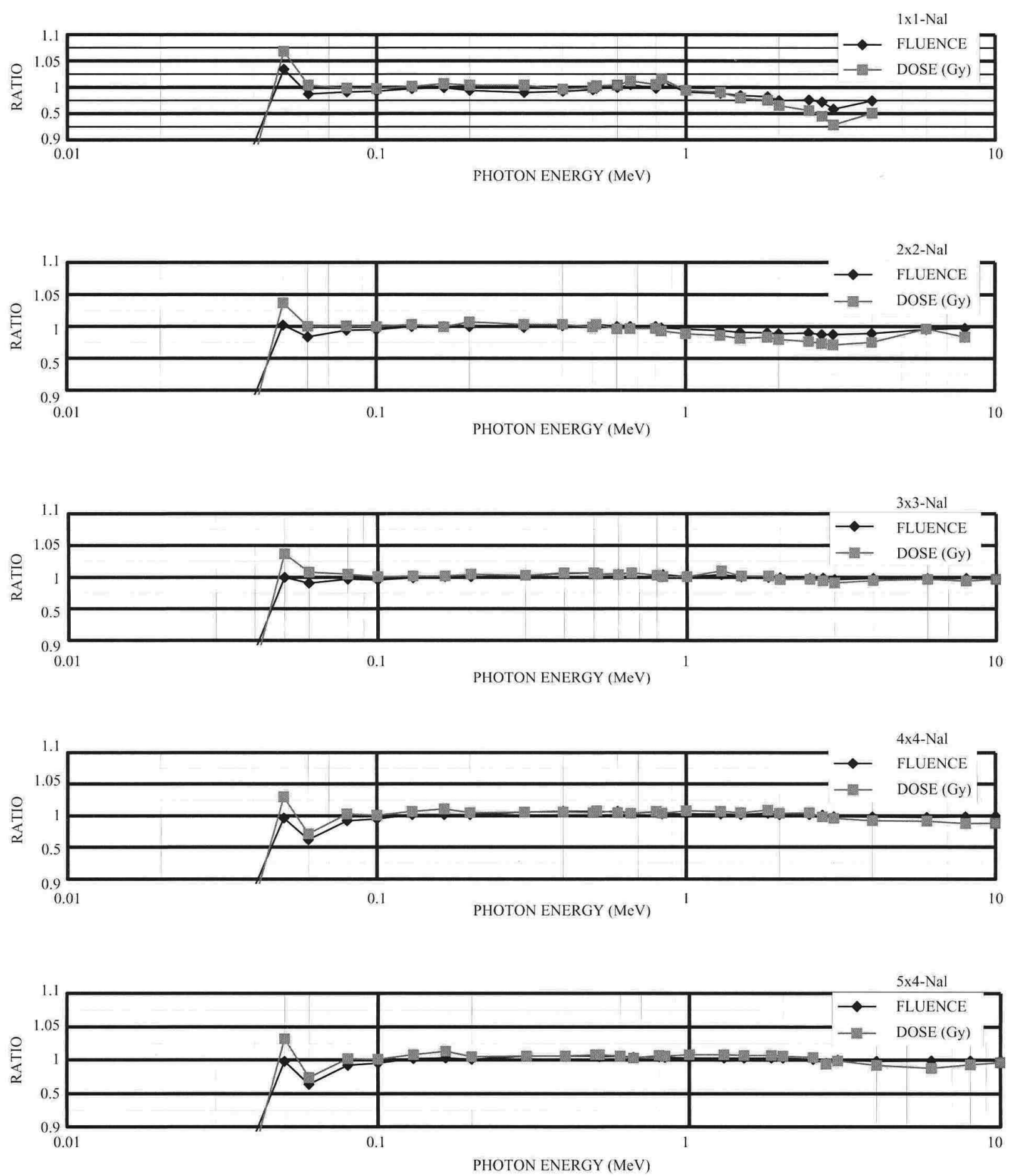

Fig. 5 Error distributions of unfolded fluence and dose by using the reproduced response matrix for the various cylindrical $\mathrm{NaI}(\mathrm{Tl})$ scintillation detectors (RATIO means the ratio of the evaluated fluence or dose to the theoretical ones.) 


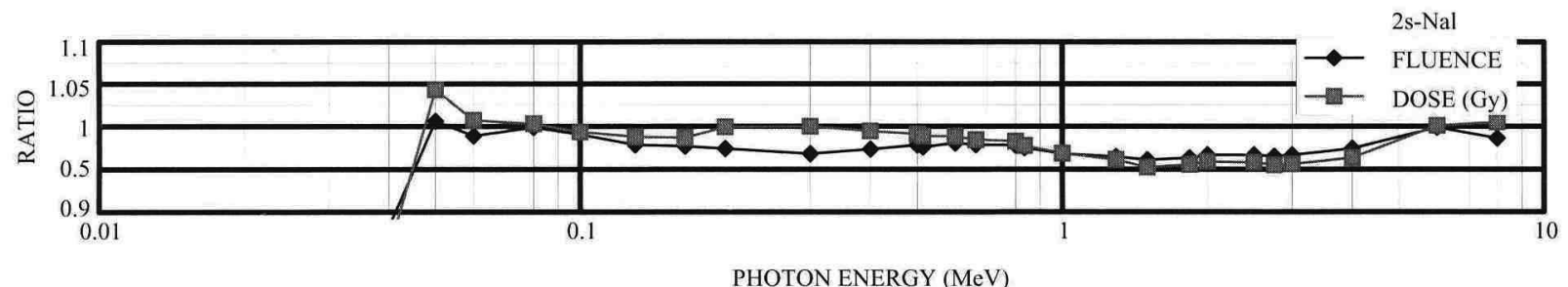

PHOTON ENERGY (MeV)
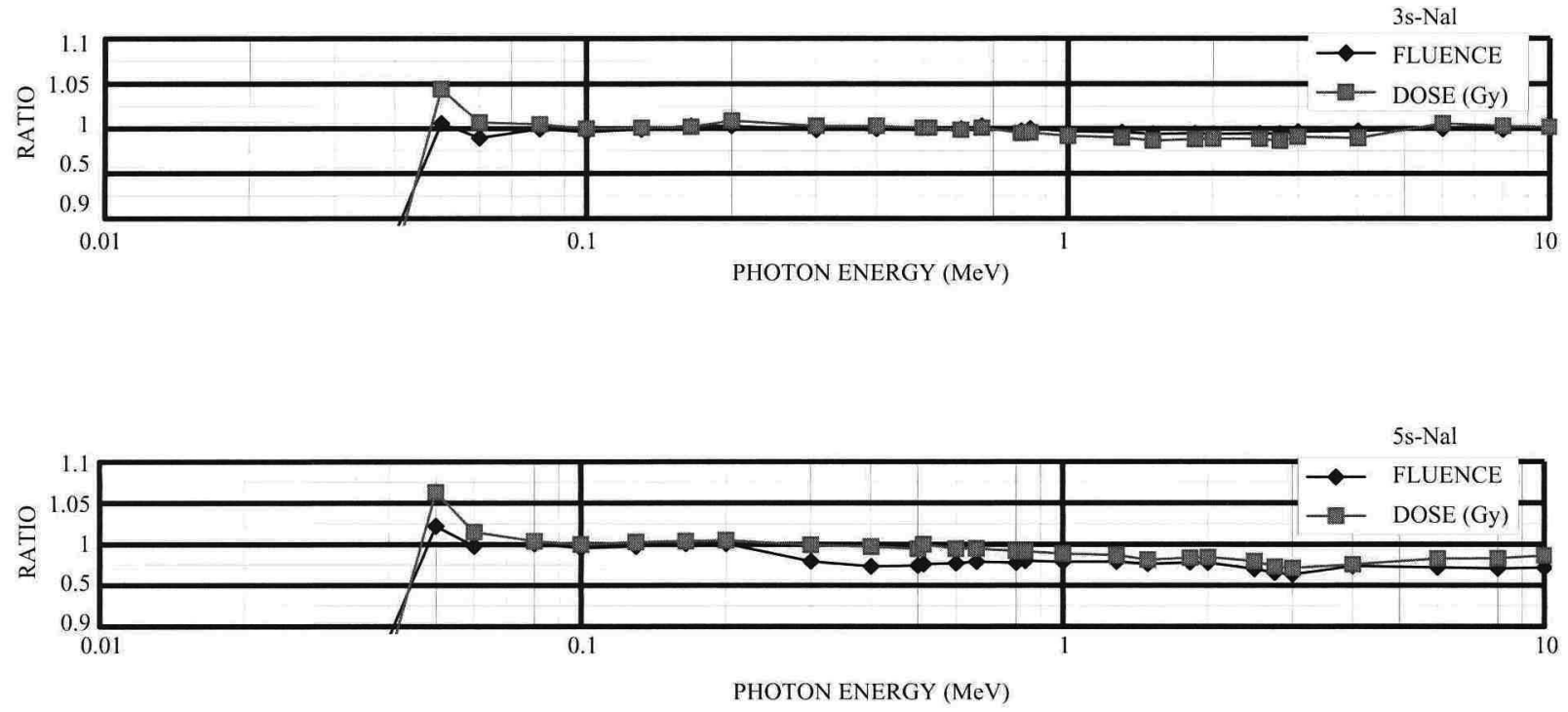

Fig. 6 Error distributions of unfolded fluence and dose by using the reproduced response matrix for the various spherical $\mathrm{NaI}(\mathrm{Tl})$ scintillation detectors. (RATIO means the ratio of the evaluated fluence or dose to the theoretical ones.)

Fig. 7 はアンフォールディングの結果であるが，この 図から, 線源の系列核種の特徴的な $\gamma$ 線エネルギーピー クが分解でき, かつ, 推測される $\gamma$ 線放出割合に大略対 応したスペクトル分布が得られていることが分かる。し かし, 線源の強度や線量率值付け值に対する定量的な精 度評価については, 線源の詳細な $\gamma$ 線放出率や線源容器 による吸収等を評価し, 検出器に入射する $y$ 線エネルギ ースペクトル，フルーエンス率を知らなければ議論でき ない。ここで, 線源の線量率に対応した線源強度の推定, 線源容器による吸収割合の評価等を行い, 可能な範囲で 解析精度の検討を実施した。

$\gamma$ 線エネルギースペクトルの解析精度を試験するには 正確な $\gamma$ 線エネルギースペクトルを知る必要がある。こ のため, 值付けされた線量率に対応した線源の強度を正 確に求める必要がある。使用した校正用 $\mathrm{Ra}$ 照射線源は $0.7 \mathrm{~mm}$ の鉄製容器に封入された公称 $100 \mu \mathrm{Ci}$ ( $3.7 \mathrm{MBq}$ 相 当）の線量校正用 $\mathrm{Ra}$ 基準線源（社団法人日本アイソト ープ協会製) である。線量率の值付けは $0.5 \mathrm{~mm}$ 厚の Pt-
Ir 合金カプセルに封入された Ra 基準線源（1mg）によ り比較法によって行われ，その誤差は土5\%である。 線量率で值付けされた線源の実質的な線源強度は以下の 方法で求めた。

先ず， ${ }^{226} \mathrm{Ra}$ の平衡状態にける全 $\gamma$ 線について Pt-Ir 壁 材と $\mathrm{Fe}$ 壁材の各 $\mathrm{Ra}$ 基準線源の容器壁材による相対的 な遮蔽の違いを計算し, 同一線源強度における線量率の 違いから校正用線源の線源強度を逆算した。ちなみに $0.5 \mathrm{~mm}$ の Pt-Ir 合金カプセルに封入された $1 \mathrm{mg}$ の $\mathrm{Ra}$ 基 準線源の距離 $1 \mathrm{~m}$ における照射線量率は $825 \mu \mathrm{R} / \mathrm{h}$ (平衡 状態仮定, Gy 単位では $7.23 \mu \mathrm{Gy} / \mathrm{h}$ 相当) である。線源 情報, 校正法, 散乱線寄与等に関する有用な情報は参考 資料 1，16）から 18）にある。

平衡状態の $\mathrm{Ra}$ 線源からは, 放出率の小さいものまで 全て含めてエネルギーの異なる 200 以上の $\gamma$ 線が放出さ れており，線量率にはこれら全ての $\gamma$ 線が寄与する。 $\mathrm{Ra}$ 線源からの線量率は容器壁材による減衰分を, 真工 ネルギー吸収係数を用いて計算し，評価した。基準線源 
の Pt-Ir 合金カプセル壁材による吸収計算については, Ir は質量, 原子番号とも Ptに近いことから, Pt の真エネ ルギー吸収係数で代用させた。線源関連の核データは参 考文献 19），質量エネルギー吸収係数は参考文献 20） より得た。線量率に対する $\mathrm{Ra}$ 線源の $\mathrm{Pt}, \mathrm{Fe}$ 容器壁材に よる減衰は $0.930,0.984$ となり, Pt 容器, Fe 容器の相 対的な差は $\mathrm{Fe}$ 容器の值を基準にして 0.945 となった。 使用した校正用 $\mathrm{Ra}$ 基準線源の線量率值付け值は $80.2 \mu \mathrm{R} / \mathrm{h}$ $(703 \mathrm{nGy} / \mathrm{h})$ であったことから, 試験で使用した Fe 容 器封入 $\mathrm{Ra}$ 線源の強度は $91.9 \mu \mathrm{Ci}(3.40 \mathrm{MBq})$ 相当となる。 これは公称值よりも約 $8 \%$ 低い值である。

Fig. 8 に, 線源強度から計算した $\gamma$ 線フルエンス率と スペクトル解析から得た結果の例を, 主要 $\gamma$ 線ピークを 中心に置いた $\gamma$ 線エネルギー群別に示した。計算結果と 解析結果の比は低いエネルギー部でやや高めの傾向を示 した。これは照射試験時の散乱線や線源の值付け精度等 が関係しているものと考えられる。なお，エネルギー群 4, 6, 8 で実測／計算比が高い值を示しているのは, 主 に, NaI 検出器のエネルギー分解能が低いため前後の大 きなフルエンス率のエネルギー群からの寄与を受けてい

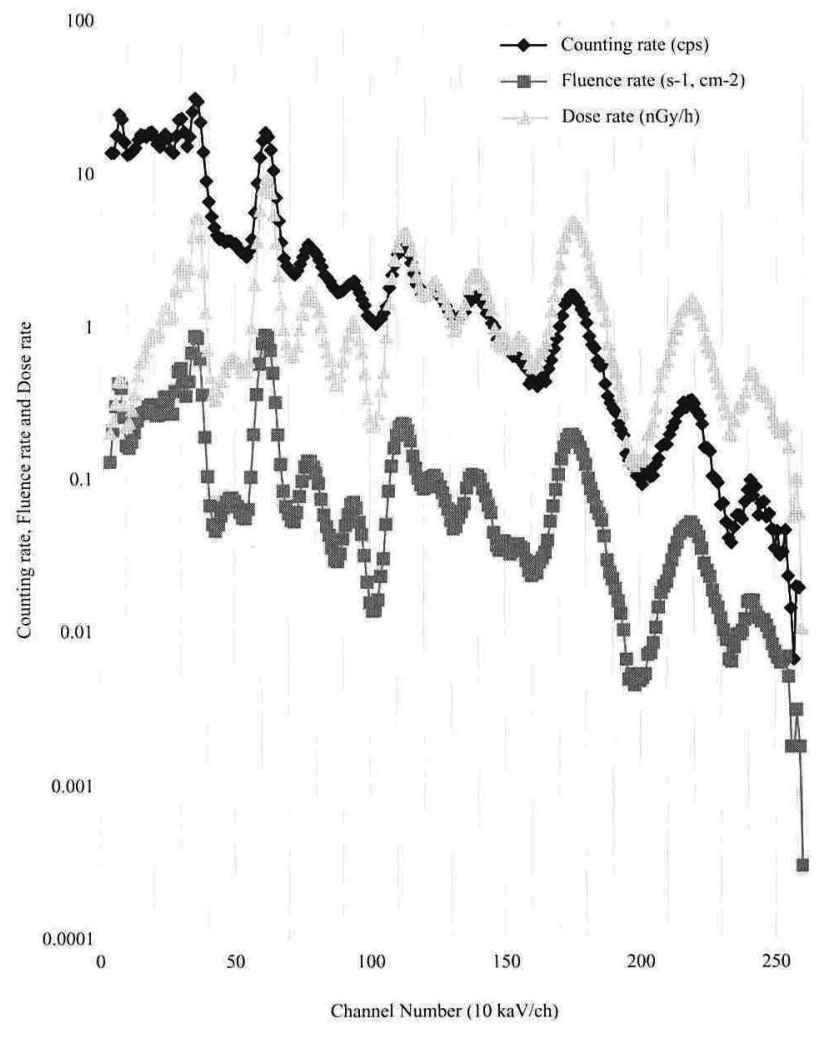

Fig. 7 Unfolding of a pulse height spectrum for radium standard gamma ray source, measured by $3^{\prime \prime} \phi$ spherical NaI(Tl) scintillation detector.
ることによるものである。

照射試験時の線源 - 検出器間距離 $(d)$ が $1.524 \mathrm{~m}$, 線 源と床面の高さ $(h)$ が $1.0 \mathrm{~m}$ で, $h / d$ 比は 0.66 であった。 試験室内での検出器配置状況（照射試験は複数の研究機 関の共同測定として行われたもので, 距離 $1.5 \mathrm{~m}$ の同心 円上に 8 個の各種の検出器が配置されていた), 線源や 検出器ホルダー等の散乱の影響等を考えると, 線量率に ついては少なくとも $6 \%$ 以上の散乱線の寄与があったと 考えられる $1,16,17,18)$ 。校正に使用した基準線源の $1 \mathrm{~m}$ 地 点における線量率 $80.2 \mu \mathrm{R} / \mathrm{h}(703 \mathrm{nGy} / \mathrm{h})$ は, $1.524 \mathrm{~m}$ の 点では $34.5 \mu \mathrm{R} / \mathrm{h}(302 \mathrm{nGy} / \mathrm{h})$ となる。 $1.524 \mathrm{~m}$ の点での 実測值が $341 \mathrm{nGy} / \mathrm{h}$ （照射線量率換算值は $38.9 \mu \mathrm{R} / \mathrm{h}$ ）で, 両者に $10 \%$ 程度の差がある。スペクトル解析結果から, 散乱線寄与はフルエンスについては約 $20 \%$, 線量率に ついては約 $10 \%$ と推定されることから，ここで整備し た応答関数を使うことで予想した妥当な解析結果が得ら れているものと結論できる。なお，より正確な評価精度 の確認を行うには, 吸収, 散乱が無視でき, 強度が正確 にわかっている放射能標準線源を用い, 散乱線寄与を正 確に差し引くことができるシャドウシールド法で照射試 験を行う必要がある。

（2）既存応答関数のアンフォールディング試験

環境放射線解析用の代表的な $\mathrm{NaI}(\mathrm{Tl})$ シンチレーショ ン検出器の応答関数として, 文科省 (旧科学技術庁) が 編纂した放射能測定法シリーズ「空間 $\gamma$ 線スペクトル測 定法」(シリーズ番号 20, 平成 2 年, 前出の参考文献 1) に代表的な幾つかが収録されている。また，その一部は 参考文献 21 から 25 に別途報告されている。

これらの参考文献に収録されている応答関数は， $2^{\prime \prime} \phi \times$

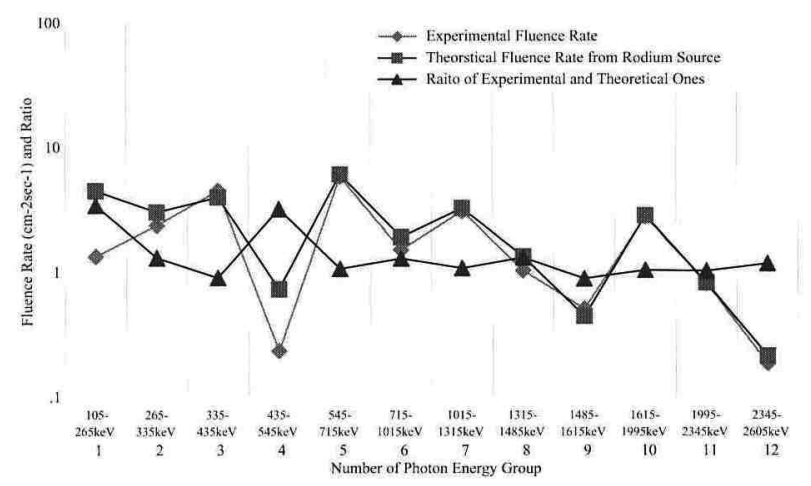

Fig. 8 Comparison of unfolded fluence rate calculated from pulse height spectra measured by a 3 " $\phi$ spherical NaI(Tl) scintillation detector and theoretical fluence rate in the radiation field exposed by a radium standard gamma ray source. 
$2^{\prime \prime}, 3^{\prime \prime} \phi \times 3$ 月筒形，及び $3 " \phi$ 球形の 3 種であるが, 同一形状の $\mathrm{NaI}(\mathrm{Tl})$ シンチレーション検出器について見 ても，エネルギービン数，エネルギー幅（共にエネルギ 一分解能に関わるもの), 応答関数そのものの形状, 等 に違いが見られる。応答関数の形状の違いには， $\gamma$ 線の 入射ジオメトリーが異なることで現れる当然の差と, $\gamma$ 線の入射ジオメトリーが同じにも関わらず応答関数の形 状が異なる絶対的な差の場合がある。ここで同じ照射ジ オメトリーの応答関数を選んで本報告で整備した内挿応 答関数行列を使ってアンフォールディングすることで, $\gamma$ 線エネルギースペクトル, 線量評価結果を比較した。 ここで示される結果は，本報告の応答関数を基準にした 相対的な差を示すものであって，本報告の応答関数が正 しいことを意味するものではない点に注意する必要があ る。解析結果は以下の通りである。なお，スペクトルの アンフォールディングについては参考文献 24 が参考に なる。

(i) 3" $\phi$ 球形 $\mathrm{NaI}(\mathrm{Tl})$ シンチレータの場合

球形検出器は, 円柱形状や特殊な形状の検出器と異な り入射放射線の方向性による感度変化がないため，精度 の高い測定に適した検出器として用いられる。先ずこの 検出器について，上に示す文献，資料に掲げられている 応答関数をここで整備した応答関数行列でアンフォール ディングすることによって相対的な違いを試験した。試 験した応答関数は 5 種類であった。応答関数毎に入射 $\gamma$ 線のエネルギー間隔，チャンネルのエネルギー幅，応答 関数列数に違いがあるほか, 応答関数がエネルギー幅の 中央の $\gamma$ 線に対応する離散エネルギーのものか，エネル ギー幅で平均したものか，等の詳細が不明な場合があっ たが，ここではエネルギー幅で平均されたものとして， 内挿した $\gamma$ 線エネルギー $10 \mathrm{keV}$ 刻みの応答関数行列で スペクトル解析を実施した。これで得られる結果は被試 験応答関数がエネルギー幅で平均された応答関数である と見なした解析結果に相当する。

$3^{\prime \prime} \phi$ 球形 $\mathrm{NaI}(\mathrm{Tl})$ シンチレータ用応答関数 4 例の結果 を Fig. 9 に示す。相対比率が 1.0 になれば評価結果はよ く一致していることになるが，図によると $\gamma$ 線エネルギ 一が低い方では 1.0 に近い結果となっていて比較的よい 一致を示しているが，高エネルギーでは差が大きくなる 傾向が見られる。極端な場合は $3 \mathrm{MeV}$ で $40 \%$ 程度の大 きなレスポンスの低下がみられる。図に示す比の值が 1.0 よりも小さいまたは大きいということは，夫々の応 答関数を使って解析した結果が図に示す比の逆数分だけ 過大に評価，あるいは過小に評価したことになる，とい
う点に注意する必要がある。以上の結果より，使用する 応答関数によって評価結果に $5 \%$ から $10 \%$ 程度の違い があることが分かる。大きいもので $+70 \%$ の過大な結果 となる。

\section{（ii）その他形状の応答関数の場合}

上に示した球形の検出器の場合は方向性のある入射放 射線の場合でも問題なく使用できたが, 円柱形の場合は, 応答関数に入射角度による違いが出るため応答関数を決 定した時の条件と同じ照射条件で比較試験を実施する必 要がある。ここで解析した応答関数は等方照射条件のも のであったが，照射ジオメトリーを無視して結晶軸並行 入射条件の応答関数により解析試験を実施した。解析し た結果は $3 " \phi \times 3 " \mathrm{NaI}(\mathrm{Tl}) 1$ 例である。結果を Fig. 10 に 示す。なお，等方入射条件に対応した応答関数で試験的 に解析した結果は，方向特性の違いを反映し，上に示し た違い以上に大きな差が見られた。方向性のない球形の 検出器を除く何れの応答関数でも方向分布が不明な放射 線場の測定では誤差を伴うものであるが, 球形の検出器 で測定した同じ場所の值を標準として補正係数が得られ るので，これを使うことで誤差の修正が可能である。

\section{IV 結訔}

測定対象の放射線レベルは目的毎に大きな開きがあ り, 従来からよく使用されてきた 3 ” $\phi$ 球形 $\mathrm{NaI}(\mathrm{Tl})$ シ ンチレーション検出器や 3 " $\phi \times 3$ ” 円柱形 $\mathrm{NaI}(\mathrm{Tl})$ シン チレーション検出器だけでは各種の測定対象に対応でき ない場合があったが，今回，より広い測定目的にも対応 できるよう，通常よく使われる球形，円柱形の大型，小 型検出器について全部で 8 種類の $\mathrm{NaI}(\mathrm{Tl})$ シンチレーシ ヨン検出器について応答関数行列の整備を行った。その 結果, 検出器のサイズ及び対象エネルギーによって多少 の精度の違いが認められたが, 通常の環境 $\gamma$ 線エネルギ 一スペクトル解析や線量評価のみではなく他の分野の測 定評価目的にも十分使える広いエネルギー範囲と精度の 応答関数行列を得ることができた。パルス波高スペクト ル情報から直接線量（率）を得る $\mathrm{G}(\mathrm{E})$ 関数を用いた線 量評価法はスペクトル解析を経ずに線量が得られること から, 従来から DBM 方式等の線量測定器に使われてき た $26-29) 。 \mathrm{G}(\mathrm{E})$ 関数計算 30 ) に使われた基本応答関数は 本報告で使用した基本応答関数と同じものであり，本報 告で整備した応答関数行列を用いたスペクトル解析（ア ンフォールディング）による方法， $\mathrm{G}(\mathrm{E})$ 関数による方 法の線量評価結果は数\%の範囲でよく一致している。本 報告により， G(E) 関数ならびにアンフォールディング 


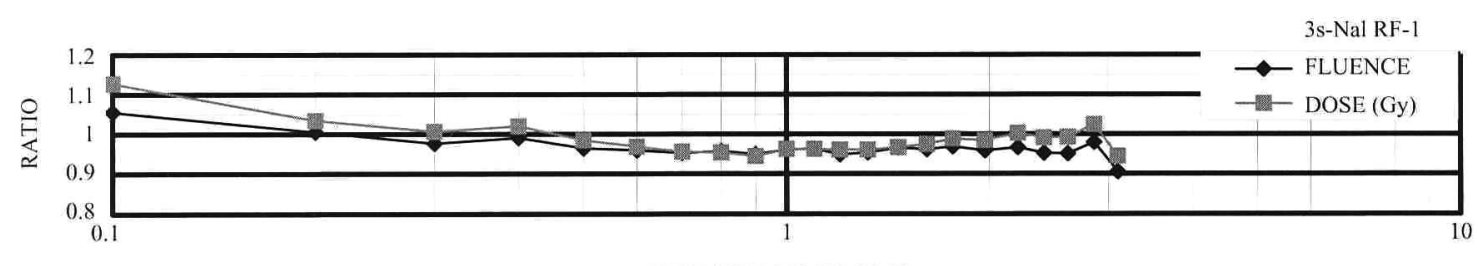

PHOTON ENERGY (MeV)

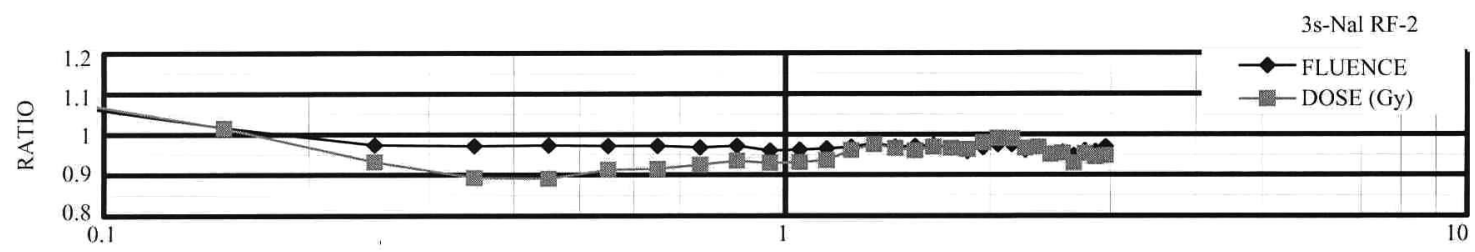

PHOTON ENERGY (MeV)

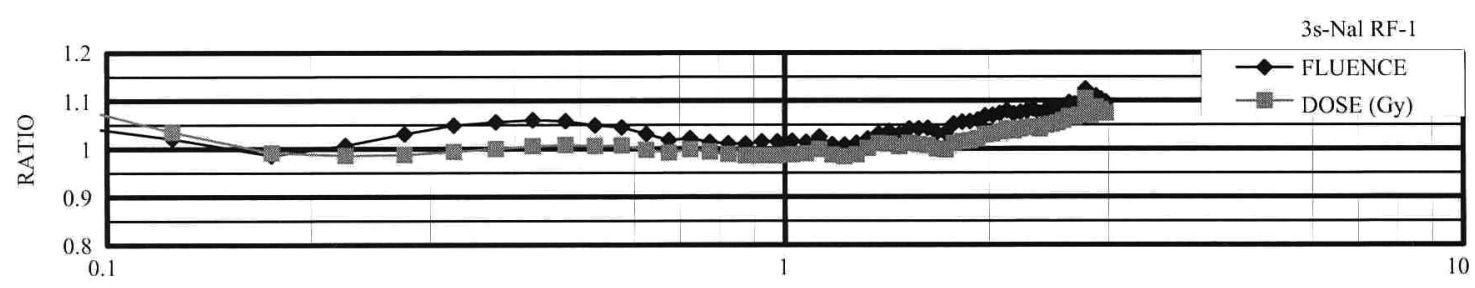

PHOTON ENERGY (MeV)

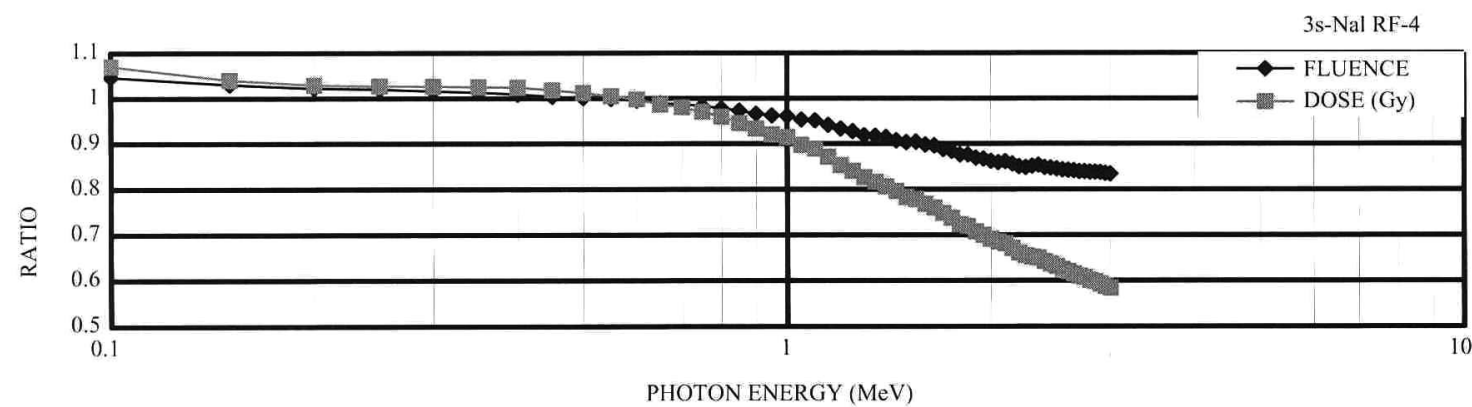

Fig. 9 Unfolded results of response functions for 3 " $\phi$ spherical NaI(T1) scintillation detectors reported in the references*), by using the reproduced response matrix.

${ }^{*}$ RF-1: analysis results of Minato's response functions ${ }^{1)}, \mathrm{R}-2$ : of Urabe's ${ }^{1,21)}, \mathrm{RF}-3$ : Moriuchi's ${ }^{1)}$ and RF-4: Okano's ${ }^{1,25)}$.

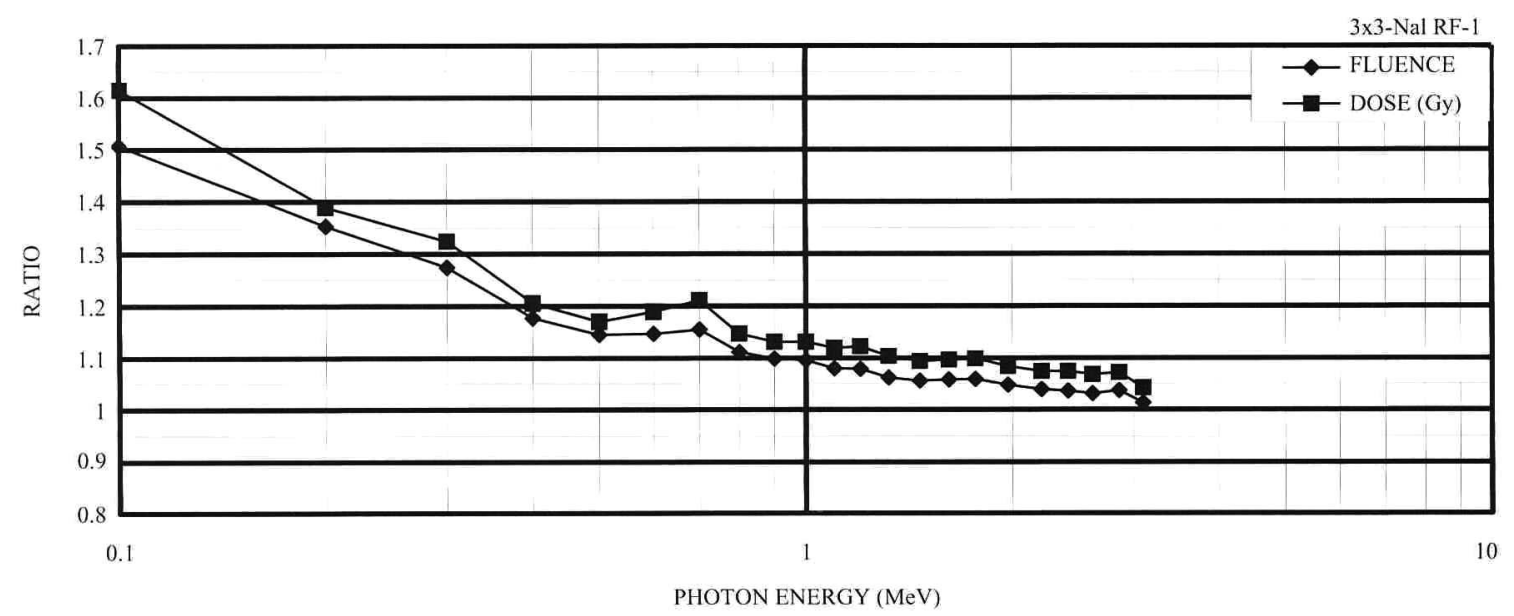

Fig. 10 Unfolded results of Minato's response functions for $3^{\prime \prime} \phi \times 3^{\prime \prime}$ cylindrical NaI(Tl) scintillation detector reported in the reference24), by using the reproduced response matrix. 
法，両方法の特徵を生かした相互補完的な測定が様々な 状況に対して可能となった。

\section{参 考 文 献}

1) 文部科学省 ; 放射能測定法シリーズ 20, 空間 $\gamma$ 線ス ペクトル測定法 (1990).

2) International Commission on Radiation Units and Measurements（国際放射線単位測定委員会）; Measurement of Dose Equivalents from External Photon and Electron Radiations, ICRU REPORT 47 (1992).

3) International Commission on Radiation Units and Measurements（国際放射線単位測定委員会）, Quantities and Units in Radiation Protection Dosimetry, ICRU REPORT 51 (1993).

4) International Commission on Radiation Units and Measurements（国際放射線単位測定委員会）; Gamma-Ray Spectrometry in the Environment, ICRU REPORT 53 (1994) .

5) International Commission on Radiation Units and Measurements（国際放射線防護委員会）; Data for Use in Protection Against External Radiation, ICRP Pub. 51 (1988).

6) International Commission on Radiation Units and Measurements（国際放射線防護委員会); Conversion Coefficients for Use in Radiological Protection against External Radiation, ICRP Pub 74 (1997).

7) K. SAito and S. Moriuchi; Monte Carlo calculation of accurate response functions for a $\mathrm{NaI}(\mathrm{Tl})$ detector for gamma rays. Nucl. Instrum. Methods, 185, 299-308 (1981).

8) K. SAITO and S. MorIUChI; Monte Carlo Calculation of NaI(Tl) Detector Response Functions for Low Energy Gamma Rays. Nucl. Instr. Meth. Phys. Res., 226, 449454 (1984).

9）斎藤公明，森内茂；モンテカルロ法を用いた $\mathrm{NaI}(\mathrm{Tl})$ 検出器応答関数の高精度計算とスペクトル形 成過程の解明，JAERI-M 9741 (1981).

10) W.R. Nelson, H. Hirayama and D.W.O. Robers; The EGS4 code system, SLAC-265 (1985).

11) 平山英夫 ; 保健物理分野の研究への EGS4 の応用, 保健物理，39(4), 328-334 (2004).

12) Briesmeister, J. F.; MCNP - , a General Monte Carlo NParticle Transport Code, LA-12625-M (1997).

13) 斎藤公明，森内 茂；モンテカルロ計算による
$\mathrm{NaI}(\mathrm{Tl})$ シンチレーション検出器ガンマ線応答関数の データカタログ；JAERI-1306 (1987).

14) T. Miura; Assessment of data and methods to form response functions of a $3^{\prime \prime} \times 3^{\prime \prime} \mathrm{NaI}(\mathrm{Tl})$ detector, $\mathrm{Nucl}$. Instrum. Methods. Phys. Res., 221, 603-608 (1984).

15) Shigeru Moriuchi, Masahiro Tsutsumi and Kimiaki SAITO; Development of a dosimetric system using spectrometric technique suitable for operational dose measurements and evaluation, 10th International Congress of The International Radiation Protection Association, IRPA-10 Proceedings, P-3b-197, Hiroshima Japan (May 14-19, 2000).

16) 文部科学省 ; 放射能測定法シリーズ 17, “連続モニ 夕による環境 $\gamma$ 線測定法”（1996 年改定）.

17）（社）日本アイソトープ協会，“放射能標準体・標準 線源とその使用法”, p. 12（1981 年 5 月 30 日発行）

18）(財) 原子力安全研究協会 ; “環境放射能および環 境放射線の計測に関する研究”，(昭和 55 年 9 月）

19) E. Browne and R. B. Firestone, V. S. Shirley, Editor; "Table of Radioactive Isotopes", Lawrence Berkley Laboratory, University of California (1986), A WileyInterscience Publication, John WILEY \& Sons, New York.

20) NIST Physics Laboratory, Online Databases, http:// physics.nist.gov/PhysRefData/XrayMassCoef/tab3.html, "X-Ray Attenuation and Absorption for Materials of Dosimetric Interest", National Institute of Standards and Technology (November 2006)

21) I. Urabe, T. Tsujimoto, K. Yamazaki and K. KATSURAYAMA; Estimation of photon energy spectra based on $34 \times 34$ response matrix, J. Radiat. Res., 19, 163 -170 (1978).

22) M. OKano; Natural Radiation Environment III, CONF780422,867 (1980).

23 湊進 ; 環境ガンマ線解析用 $3^{\prime \prime} \phi \times 3^{\prime \prime} \mathrm{NaI}(\mathrm{Tl})$ シン チレータのレスポンス行列, 名古屋工業技術試験所 報告，27，384-397 (1978).

24) 湊進 ; 応答行列法による環境ガンマ線波高分布 の解析, JCAC, 32, 2-13 (1998).

25) 岡野真治; 環境放射線量測定法, JCAC，32,14-27 (1998).

26) 宮永一郎, 森内 茂; 日本原子力学会誌, 9(8) 440446 (1967).

27) 森内 茂, 宮永一郎 ; 日本原子力学会誌, 9(9) 518523 (1967). 
28) 森内 茂; スペクトルー線量変換演算子による線量 評価法とその演算子の決定，JAERI-1209（1971 年 7 月).

29) 森内 茂; スペクトル荷重関数方式による環境 $\gamma$ 線 線量測定器に関する研究，JAERI-M 7066（1977 年 5 月).

30) 堤 正博, 斉藤公明, 森内 茂; 実効線量当量単位 に刘応した $\mathrm{NaI}(\mathrm{Tl})$ シンチレーション検出器の $\mathrm{G}$ （E）関数（スペクトル－線量変換演算子）の決定,

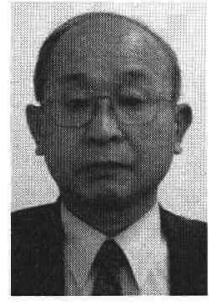

森内 茂（もりうち しげる）

和歌山県出身。昭和 34 年に日本原子力 砌究所に入所し，一貫して環境放射線を 対象にした線量测定器・測定法に関する 研究，環境放射線モニタリング法の技術 開発に従事。平成 7 年以降, 原子力安全 技術センターにおいて緊急時環境放射線モニタリング, 環境線量予测関連の業務に従事。工学博士 (東京大学)。 E-mail: moriuchi@oregano.ocn.ne.jp JAERI-M 91-204（1991 年 12月） 